\author{
Historical Studies in Education / Revue d'histoire de l'éducation \\ SPECIAL ISSUE / NUMÉRO SPÉCIAL \\ Education North of 60 / Éducation au nord du 60e
}

\title{
The University Project in the Canadian North, 1964 to 2014
}

\section{Amanda Graham}

\begin{abstract}
Since 1964, there have been four periods in which a northern university for the Canadian territories was proposed or attempted. The first, from 1964 to 1982, coincided with such motivating national forces as post-war expansion and renovation of the post-secondary sector with new universities and community colleges, northern development, and land claims. In the second stage, from 1983 to 2000, the territorial governments established Yukon and Arctic colleges, both institutions with some university-like features. During the third, "circumpolar," period, from 2001 to 2011, the Arctic world opened up and the University of the Arctic network was established. The fourth, "academic," phase began on October 14, 2014, when the Yukon Government and Yukon College Board of Governors jointly announced the college is developing a degree and a post-graduate certificate for launch in 2017. Northerners and others who have advocated for a northern university may now finally witness the emergence of such an institution, one that will meet the varied needs of residents of the North.
\end{abstract}

\section{RÉSUMÉ}

Depuis 1964, on peut compter quatre périodes lors desquelles des tentatives ou des propositions d'une université nordique ont été faites pour les territoires canadiens. La première, entre 1964 et 1982, coïncida avec une motivation des forces nationales inhérente à l'expansion de l'après-guerre et à la revitalisation de l'enseignement postsecondaire avec la création d'universités et de collèges communautaires, le développement du Nord et les revendications territoriales. Dans la deuxième période, allant de 1983 à 2000, les gouvernements des territoires établirent les collèges Yukon et Arctic, des institutions s'apparentant à des niveaux universitaires. La troisième période dite circumpolaire, de 2001 à 2011, le monde arctique franchit une étape et établit le réseau des universités de l'Arctique. La quatrième phase surnommée l'académique débute le 14 octobre 2014, alors que le gouvernement du Yukon et le Conseil des gouverneurs du Collège du Yukon annoncent conjointement la création d'un diplôme et d'un certificat " post-gradué " qui entrera en vigueur en 2017. Les habitants du Nord et tous ceux qui ont défendu l'idée d'une université nordique peuvent dorénavant saluer l'émergence d'une telle institution qui va répondre aux besoins des résidents nordiques. 


\section{Introduction}

On 14 October 2014, Yukon College and the Government of Yukon held a wellattended press event to announce the establishment of the first "made-in-the-North" bachelor's degree. ${ }^{1}$ The new Yukon College degree, of policy studies in Indigenous governance, should have elicited cheers and celebrations across the North, in the South, and around the circumpolar world. That did not happen.

For fifty years, various people have promoted the idea that the Canadian North should have a university. Sometimes that promotion amounted to little more than letters and talk. In a few cases, the idea led to action. In almost all instances, proponents sought to secure government support for their university; some also attempted to build community support to get government to act. Since 1964, there have been at least ten of those instances. Each of them represented a moment when it was imagined that a university rooted in - and of - the North would create the stability, social order, and problem-solving that underpin a strong and self-reliant society. The October 2014 degree announcement, along with a post-graduate certificate in climate change, was the first firm, publicly endorsed, step in the transition of the college into a "new generation university." 2 The muted response, given that the event marked the culmination of decades of effort toward that goal, was curious. ${ }^{3}$

The answer may lie in the fact that notions of what a northern university was for, and what it would do, have changed over the last fifty years in tandem with the evolution of northern society itself, and have been coloured by new expectations of universities and academic knowledge. Through a long-running, but perhaps largely unremarked process, the North's interest in, need for, and capacity to support a university (or universities) has changed and expanded. More and more Northerners, Aboriginal and non-Aboriginal alike, have come to believe that to achieve the kind of future they wish for themselves, their people, and the territories, they must have centres of higher education, professional training, and research situated in the North and answering northern needs and questions. This article will trace the evolution of those beliefs by analyzing the development of proposals for a northern university over the fifty years beginning in 1964, and will show how, in each of four distinct periods, these initiatives contributed to both growing expertise and changing expectations for such an institution.

\section{The New Universities}

In the late 1950 s and early 1960s, as the baby-boom generation reached universityentrance age and enrolments swelled, the "new university" phenomenon developed in southern Canada. Murray Ross, president and vice-chancellor of York University, documented the phenomenon in New Universities of the Modern World. He concluded that interest in and support for these institutions was a product of "new convictions about science, about nationalism, about economic development, [and] about human dignity." Influences emanating from Europe and the United States had modified ideas about higher education and, with new emphasis on research, universities came 
to be thought of as the problem-solvers of society. ${ }^{5}$ Though similar in some ways to pre-war institutions, the new universities lacked the old image of "absent-minded professors and...ivy-covered walls"; their local communities felt a sense of proprietorship, and put them "in the public domain in a manner, and to a degree, uncommon in the past." 6

These ideas took some time to reach the North. Scientists, explorers, and other Western observers had conducted research there for decades, but their work was for export, with little of benefit remaining in the region. In addition, well into the twentieth century, the North's educational capacity was minimal, where it was not entirely non-existent. ${ }^{7}$ Up to the 1960 s, the sparse population residing in the North was largely Aboriginal, widely dispersed, and oriented to renewable-resource-based lifestyles. A traditional university was financially inconceivable. By the 1960s there had been sufficient change and development in the Yukon at least - new power-generating facilities, improved infrastructure, school and hospital construction, etc. - that, along a growing cadre of North-oriented academics at southern universities, a university in the North seemed possible. ${ }^{8}$

\section{First Ideas and False Starts: 1964 to 1982}

During the first stage of the "university project" in northern Canada, from 1964 to 1982, no fewer than six separate individuals and groups, northern and southern, proposed such an institution. In late January 1964, W. E. "Ernie" Senior, manager of the Churchill Port Commission, and, from 1965, publisher of the weekly Taiga Times, pointed out in the Churchill Post that the closing of the Defence Research Board Laboratory in Churchill would leave "buildings and equipment that [had] cost the taxpayer many tens of millions of dollars." They were just the thing for an impressive Centennial project. In his view, people who were "at all familiar with the requirements of the university campus," especially one suitable for northern Manitoba, would be "STUNNED by the fact that here is a ready-made opportunity" [his emphasis] for the country to inherit a "practically made-to-order Northern University for research" into Arctic and subarctic problems. ${ }^{10}$ Senior was known for wild-eyed schemes and this one looked like another. ${ }^{11}$ In this instance, however, he was quite serious: his university "City" would keep "the cream of our youth [from having] to leave Churchill to seek further training and opportunity." It would also offer "a research centre to find what the north needs and deserves." 12 The Winnipeg Free Press called his idea for a "University of Northern Research and Development" a "novel and original proposal." 13 Senior had reason to think that his idea would be taken up by government. In an October 1964 article in Maclean's, he said that Manitoba Premier Duff Roblin and Minister of Northern Affairs and National Resources Arthur Laing were impressed and that the Prime Minister had been informed of the idea. ${ }^{14}$ That, however, was as far as it went. The province told Senior it was a matter "of particular concern to the federal authorities, [so] the initiative must clearly come from them." The Prime Minister's office sent it back to the province: "the initiative for establishing a university... would be a matter of jurisdiction of the 
provincial government." ${ }^{15}$ And there the matter rested.

In April 1964, another university proposal, this time for Dawson City, Yukon, hoped to staunch the outflow of youth. ${ }^{16}$ Like Ernie Senior in Churchill, Alan InnesTaylor and Iris Warner thought a Dawson university would be a worthy Centennial project. Dawson had buildings that might be suitable: the former Commissioner's residence and the Old Territorial Government Building had been unused since the seat of government had moved to Whitehorse in 1953. Innes-Taylor, a former Mountie and outdoorsman, and Warner, a journalist, wanted their university to "bring together the adventurous youth of Canada to train for the development of the vast Northern Empire." 17 Dawson City, they thought, with those handy unused buildings, could benefit greatly. Indeed, life as a university town would be the "beginning of a new economy for the area... an isolated and historic part of Canada." 18

Warner wrote to a friend with contacts at the Ontario Institute for Studies in Education in Toronto. ${ }^{19}$ In reply, he told her that the project would be very expensive and difficult, and might be best conducted as an extension project of a southern university. She then tried to find government support by enlisting the assistance of the former Minister of Northern Affairs and National Resources, Walter Dinsdale, with whom she was acquainted. He found the idea interesting but told her it should be taken to the Yukon Territorial Council, to the Dawson councillor, George Shaw, and to the Yukon Commissioner, Gordon Cameron. Warner reported, somewhat sourly, that Shaw had not been "overly impressed" with the "practicality of the scheme" and that "perhaps a talk with the Commissioner will suggest a way." Further efforts failed to attract support.

A third project for higher education was, for a short time, very successful. The Mackenzie Institute was established in Inuvik, NWT, in October 1968 by Dick Hill, Agnes Semmler, Victor Allen, and three others. ${ }^{20}$ A grass-roots educational institution, it was to be "directed to northerners and their well-being through the provision of academic, extension and research activities" and to "provide for the public educational needs of Western Arctic residents not met by the regular primary and secondary schools." ${ }^{21}$ Plans included offering first- and second-year university courses, and co-ordinating and advising Western Arctic academic and research programs.

The institute led an active existence for just a few years. It held a ten-lecture series on aspects of the Mackenzie Delta in 1968. ${ }^{22}$ Later, in November, 1970, it co-sponsored the "Man in the North Conference" with the Arctic Institute of North America, so Northerners could "identify priorities for research in northern community development." 23 Hill recalled that Victor Allen, an Inuvialuk and the institute's Vice-President, served as "eskimology Professor," and gave lectures on Inuvialuit language and culture. ${ }^{24}$ The institute also ran a program that informed residents about oil and gas exploration and facilitated communication between the exploration companies and Delta communities. And as we shall see, the institute also connected Inuvik, literally, to southern researchers for a time. In 1971 it folded on its own initiative, relinquishing its "responsibilities" to the Inuvialuit when their land claim body, the Committee for Original Peoples Entitlement, opted to assume them. ${ }^{25}$ 


\section{Three Southern Ideas for Northern Universities}

Canadian universities began to pay more attention to the North in the 1950s and 1960 s, a period of great interest in the polar regions. Several permanent research stations and specialist university institutes devoted to the study of the North were established. Among the first were the joint American-Canadian Arctic Institute of North America, 1944-45; ${ }^{26}$ the McGill Sub-Arctic Research Station at Schefferville, Quebec, in 1954; $;^{27}$ and, in 1960, the Boreal Institute for Northern Studies at the University of Alberta and the Institute for Northern Studies at the University of Saskatchewan. The University of Calgary established its Kluane Research Station in 1961, the same year the Centre d'études nordiques at Université Laval was founded. Other research stations and institutes followed.

Fundamental changes in universities during this time also contributed to their relevance to the northern university project. The two decades after 1950 witnessed enormous ferment and growth, with expanding programs, new fields, and increased student enrolments. ${ }^{28}$ The growing, but still limited, interest in the high latitudes meant there were rarely enough university scholars of the North to meet the government's need for data to inform policy and decision-making. The 1961 Northern Scientific Training Program was developed to mitigate the problem with modest amounts of additional funding to university research programs, to enable more students to go north for field work. ${ }^{29}$ Greater numbers of scientists were heading north and, for the most part, they brought their ideas in and their impressions out.

One of these scientists was glaciologist Peter Adams, a frequent research visitor to the Arctic and the founding head, in 1968, of the Geography Department at the new Trent University in Peterborough, Ontario. ${ }^{30}$ His Trent experience convinced him of the benefits a university could have on a community, and he wished the same for the North.

In correspondence that lasted for more than two years, Adams tried to provoke interest in moving forward with a university in the North. ${ }^{31}$ His efforts were initially directed to the Hon. Jean Chrétien, then Minister of the Department of Indian Affairs and Northern Development (DIAND), and later to a wider audience as Adams' interest in the university project expanded. In Chrétien's view, a northern university was "impractical" for reasons of geography (any given student in the North was likely closer to a southern university than to one in, say, Yellowknife) and expense (as it was, secondary education in the North was "roughly double" the cost per student in the South. A university would "face far greater problems."). If, he said, there were any reason to introduce university education into the North, it would be best done by expanding the services of the Inuvik Research Lab or building on existing programs, like University of Saskatchewan's Rankin Inlet Institute of Northern Studies. ${ }^{32}$

The Yukon Territory Commissioner, Jim Smith, received and forwarded copies of the Adams-Chrétien correspondence to the Department of Education. Superintendent R.L. Shields told Adams he was very interested in the proposed "University of the Arctic" and thought it would be possible to make a small start right away. ${ }^{33}$ Adams replied that he would be pleased to help and added that he had been 
disappointed with Chrétien's response. A university, he thought, would have many benefits beyond providing education. It would lead to greater continuity of study results; it could co-ordinate northern research; and it would "bolster general development of the North." ${ }^{4}$ For more than a year, Adams continued to seek information about and encourage other contemporary attempts to establish a university. While he was never entirely sure how a university in the North would be established or how it would function, he never ceased to believe it was a good idea. ${ }^{35}$

A small group of University of Western Ontario (UWO) academics also developed an interest in creating a northern university, leading them to connect with many other people across the country. ${ }^{36}$ In 1969, in a university seminar, Phoebe Nahanni, a Dene undergraduate student, challenged the academics to bring the academy to the North. ${ }^{37}$ The group canvassed faculty and John Hart, a professor in the Computer Science Department, roughed out a concept of a "university of the air" based on a microwave communications network. A computer-assisted instruction (by teletype) proof-of-concept project was piloted with Inuvik. The success of the test led the group to contact a number of people, including Peter Adams, and several professors of education, notably at University of Saskatchewan, who were already working on teacher education programs in the NWT. For a year or more, this group was a notable participant in the southern discussion of a northern university.

Unlike Adams' vision of the northern university, premised on the research ideal and on social and economic benefits, the UWO/Saskatchewan group focused on delivery and assumed the problem to solve was access and teaching. Their goal was to connect South to North so that students would not have to leave their communities to attend university. There were other considerations. During this period, when teacher education programs for northern communities were first being developed, there was anxiety about possible culturally destructive effects of teacher training on northern Aboriginal cultures. ${ }^{38}$ The talk of establishing a university in the Canadian North raised, for some scholars, the same moral and ethical questions being raised in the teacher education circles and about new universities in recently decolonized regions in Africa. ${ }^{39}$

There is one more piece of the university project in this period, the most visible and, in many respects, the culmination of the attempts that accompanied it. It began, in part, in Toronto in the mid-1960s, when Richard Rohmer, a lawyer, decided to run (unsuccessfully) for Parliament. His platform was "mid-Canada" development, focusing on the swath of boreal forest that ran across the country and up into the Yukon and down the Mackenzie valley in the NWT. ${ }^{40}$ He established a foundation, commissioned a study, and organized a conference involving two annual sessions (1969-1970) and study tours to subarctic regions. His efforts, however, to forge a national consensus on developing the mid-Canada "corridor" failed to secure endorsement. ${ }^{41}$

In 1970, Jim Lotz, a man with experience in northern social development, published Northern Realities: The Future of Northern Development in Canada. The core of his argument was that northern development had to focus on "real people": it had to enable, he insisted, "a widening of horizons... allowing people to develop their 
potential." ${ }^{42}$ The seasonal presence of researchers, he thought, was already a kind of university, but an ineffective and unco-ordinated one. Like Adams, he knew that continuity of data required local researchers. Furthermore, lack of co-ordination had locals "getting fed up with being pestered and asked the same questions over and over by outsiders." So, Lotz argued, rather than being a "wild idea," a northern university seemed to be "one of the last chances for a sane and rational approach to northern and national development," and a catalyst for community growth. ${ }^{43}$

The book inspired people ready to hear its message, and among them was Richard Rohmer. He was entirely taken with the arguments and, early in summer 1970, after reading it on a trip to Inuvik, feverishly worked out how to make it happen. ${ }^{44}$ $\mathrm{He}$ drew on his various connections to rally interest and to raise funds. He enlisted some fifty people in Inuvik, Yellowknife, and Whitehorse, and later Fort Smith, to participate. In January 1971, on their behalf, he applied for federal letters patent for a university corporation. While Rohmer was credited for his energy and enthusiasm behind the organizing, he also bore criticism for the appearance that the project was somehow connected with his Mid-Canada Development scheme. Rohmer insisted that he was merely a facilitator and his goal was for the project to be entirely driven by Northerners.

In mid-March 1971, the University of Canada North (UCN) came into legal existence as a complicated organization of two territorial "divisions," each with its own board and executive, linked by a joint UCN Executive Committee. ${ }^{45}$ University development seemed feasible, and the public accepting, despite claims of some unhappy territorial education officials who felt blind-sided by the incorporation. The idea was disparaged by some who thought that a small northern university couldn't possibly offer sufficient "depth of educational experience." "Nothing," a commentator sniffed, "is quite as useless... as a small and inadequately equipped institution of higher learning." ${ }^{46}$ Aboriginal reaction was lukewarm and tainted with suspicion and doubt. The Indian Brotherhood of the Northwest Territories soon issued a press release accusing the founders of not consulting Northerners. ${ }^{47}$ Some of the founders were, in fact, Aboriginal people, but recently formed Aboriginal action groups, including Yukon Native Brotherhood, Indian Brotherhood of the Northwest Territories, and Committee on Original Peoples' Entitlement, were troubled that they had not been consulted or even informed in advance. ${ }^{48}$ Once the university corporation was formed, the interim directors began discussing how they were jointly going to address criticism and fulfill the promises they had made in the incorporation documents.

The incorporation application asserted that "present education programs in Northern Canada represent one of the greatest failures as it relates to Native People" and that "a Native-controlled University" was necessary to preserve Aboriginal identity and to "train large numbers of Native people...for leadership with the Native community." ${ }^{49}$ Thus the UCN gave primacy to "the self-determination of the Native People who live north of sixty." It would become a resource centre for their use, and, as an educational institution, would "train its students in leadership, community development and legislative process with programs for persons at all levels of previous education and for all age groups." The final resolution promised a 1972 
constitutional change to ensure that "Northerners of Native origin" would be the majority of directors.

Their declared objectives, however, bore little resemblance to those grand social justice aims. UCN was going to "advance learning and disseminate knowledge respecting the social and physical sciences in relation to Mid-Canada and Arctic Regions." It would do that with "faculties, schools, institutes, departments, chairs, and courses" and whatever supporting funding and legislation it secured. It looked like a traditional Western institution, which was part of the problem the UCN faced almost immediately. It was also difficult to encompass the multiple, diverse, and conflicting, social and educational expectations of Northerners. A university in the North would need to be designed for, and responsive to, northern conditions. It would have to meet the urgent needs for research, knowledge generation, and innovation in many fields. ${ }^{50}$ For newly politically active Aboriginal peoples, a university was a possible vehicle for political, social, and cultural advancement. ${ }^{51}$ But to other Northerners, ecstatically happy with the grants that enabled their children's education in the South, a local university was a threat to their benefits.

To reach consensus on what UCN needed to be, the directors organized a "Concepts Conference" for November 1971 in Inuvik. ${ }^{52}$ In advance of the conference, the directors received various unsolicited suggestions: the UCN should be a "centre for native culture or... a source of information on how to operate in the North," or it should be a "research centre or...specialty campus with students from all over the world coming to learn about the North." ${ }^{53}$ The conference itself gave three of the new Aboriginal organizations time to think about the university and plan a response. There was some academic interest in the project, primarily because of the declared openness to Aboriginal participation and direction. ${ }^{54}$ However, the two days of lively discussion at the Concepts Conference, attended by Canadian and foreign experts and interested people including some press, left many thinking that the project had been rushed.

The two UCN divisions had different trajectories. The NWT Division's directors had hoped to expand higher education opportunities for students there but, challenged by the difficult and expensive requirement to meet regularly, and preoccupied with the weaknesses of the school system, had to lower their sights. After a year-long struggle to find funding, the NWT Division undertook a final "College North" project in 1973, which studied community post-secondary needs and desires. ${ }^{55}$

The Yukon Division (UCN YT) Board functioned into the late 1970s and limped into the 1980s. It tried to offer some teacher training and land-based courses in renewable resources, undertook National Film Board distribution, and ran a successful series of land claims forums (1976). Its "Research Division" operated as a one-man shop for social research, involved itself in regional and national discussions of northern science policy, developed a proposal for a Yukon Research Co-ordinating Centre, and conducted several pipeline impact studies. ${ }^{56}$ By 1980, one of the original applicants and Yukon Board member, Garth Graham, could see that conditions had changed over the decade. The UCN project of research and education and "of what the U.C.N. might or might not become," he lamented, "is now circumscribed 
by [DIAND] proposals for a Whitehorse Research Centre and by a Territorial Government post-secondary education study." ${ }^{27} \mathrm{He}$ felt that there was yet need for an institution to play "a role in cross-cultural contact and social comment." ${ }^{2}$ The UCN continued, weakly. The motivating force behind the Research Division died in 1982 and Graham left the territory in 1983. There was no one left to carry the torch. The corporation was wound down in 1985. A proposed new Whitehorse Research Centre was announced with fanfare by Eric Nielsen during the 1980 election campaign, but not, ultimately, built. ${ }^{59}$ The Yukon government was encouraged (some say pushed) by the UCN project to undertake, in the late 1970s, a territory-wide survey of community aspirations for post-secondary education. UCN, a southern idea that was tried on for size, might not have succeeded, but it pointed the way forward, one that took a more practical route to providing post-secondary education.

\section{Community Colleges: The Practical Solution, 1983 to 2000}

The UCN experience had shown that Northerners wanted expanded post-secondary opportunities, so the territorial governments explored the options. The UCN episode had also shown that a university was probably not the best institution to satisfy varied northern demands. Their commissioned surveys revealed widespread support for a community college approach. Community colleges like those in the western Canadian provinces, with their comprehensive curricula and mix of programs, were ideal: a single institution could offer a greater variety of training and education opportunities to a greater range of people than a university. ${ }^{60}$ According to Aron Senkpiel, founding dean of the University Transfer Division at Yukon College, a modest community college "fit the actual educational needs and economic resources of the community." ${ }^{1}$ So the drive was on. The 1981 Thebacha College became the multi-campus Arctic College in 1984. ${ }^{62}$ The 1963 Whitehorse Vocational School in Whitehorse merged with a UBC extension B.Ed. program to become Yukon College in 1983. With the creation of the colleges and the possibility of local professional and vocational training and education, talk of a university subsided.

One important limitation of the community college model for the North was its indifference to research. Without research institutes or universities within reach, this was a more serious problem there than elsewhere in Canada. As the sole territorial institutions of higher learning, the colleges would have limited ability to help shape northern society without expanded services; they needed a modest capacity, at least, for research. The Science Institute of the Northwest Territories (SINT) was legally responsible for co-ordinating, managing, and licensing research, and was able to attract academics to augment limited resident research capabilities. ${ }^{63}$ The Yukon did not have a legislated body with such functions. Research co-ordination was ad hoc and licensing handled by the Heritage Branch. Yukon College had to find creative ways to work research into its activities.

Housed on its new Ayamdigut campus in Whitehorse after mid-1988, the College undertook to develop some in-house research capacity with Northern Studies as the focus. ${ }^{64}$ The two-year, undergraduate Northern Studies diploma program was 
designed to prepare graduates for either entry-level employment in the North or for university transfer. It would also "provide a foundation for relevant applied research and training." "S5 Senkpiel envisioned Yukon College as a community-college-plus, the "plus" partly being research. He encouraged it in his faculty and engaged in scholarly activity himself. ${ }^{66}$ The Northern Studies program was supported by a research fund endowed by the territorial government at the opening of the new campus. A scholarly journal, The Northern Review, completed the triangle. The research would appear in the Review, and the new knowledge would be integrated into the Northern Studies courses.

In the NWT, geography and history ensured challenges. Gail Hilyer's account of higher education in the NWT reveals the difficulties in establishing and delivering community college programs for the entire territory. ${ }^{67}$ Before its division into NWT and Nunavut, there were sixty-six communities, ${ }^{68}$ few of which were on yearround ground transportation routes. In the late 1990s, four centres had populations of about 3,000 and only Yellowknife exceeded 10,000. The Fort Smith Thebacha College (established on the basis of a pre-existing vocational school) was reorganized into the NWT-wide Arctic College in 1984 with three, then four, campuses - at Fort Smith, Yellowknife, Inuvik, and Frobisher Bay/Iqaluit - and with learning centres in many communities. In 1992, Arctic College began to prepare for territorial division by reorganizing into a new college, Nunavut Arctic College, for Nunavut, and another new one, Aurora College, for the remainder of the NWT. ${ }^{69}$ Division took effect on 1 January 1995. SINT was divided, too, and the halves were amalgamated with the new colleges, giving each care and oversight of research in their respective jurisdictions. Both, then, were "colleges-plus" from the start. Limited funding and capacity, however, left most research in the hands of imported or visiting researchers.

In the Northwest Territories, as in the other territories, demand grew for programming beyond the college diploma level, particularly in nursing and teaching, and for programs in more fields. Maybe it was time for a university college. The government circulated a discussion paper on "University College Development in the Northwest Territories" in $1998 .{ }^{70}$ But the growing desire for higher education had to be balanced against the continuing needs of adult learners without such aspirations and, while the Aurora College corporate plan for 1995-2000 had seemingly set the college on the path to becoming a university college, it has, to date, not taken the final step. ${ }^{71}$

Across the North, in the absence of nearby universities, tailored professional degree programs (e.g., B.Ed., B.S.W, B.Sc.N., etc.) became regular offerings, brought north by or from partner universities and offered on-site. One-off degree programs, such as Masters in Community Health, Education, and Educational Leadership, M.B.A., and LLB, were occasionally arranged in response to identified need and also accredited by partner universities. These often-expensive programs allowed the colleges to respond quickly to changing needs and yet avoided obligating the colleges to establish faculties of their own. For students with interests beyond these, government grant programs continued to help them study "Outside."

In the community college period, then, the demand for a northern university was pacified by the brokered degree programs and by financial support to study at 
southern institutions. Internal encouragement to research helped the colleges to be recognized among their peers: in 1990, they were welcomed into the Association of Canadian Universities for Northern Studies (ACUNS). Loosened membership criteria let the colleges take their place as equals. Their expertise in northern matters was respected. While there was hope that ACUNS membership would enable research collaborations, in practice research still tended to be conducted by non-residents. During the community college period, however, there was growing insistence that research be carried out on northern terms and for northern purposes. The South started listening.

Changes in the northern political and social environment were signalled by such events as the land claims negotiations and settlements of the 1980s and 1990s, and the collapse of the Soviet Union in 1991. The establishment of the Arctic Council in 1996, with international and multi-ethnic Indigenous organizations as Permanent Participants, made clear that an expanded view of the North would be key to future opportunities. Educated Northerners now also needed knowledge of the circumpolar world.

\section{Growing Circumpolar: University of the Arctic, 2001 to 2011}

The University of the Arctic (UArctic) is a co-operative network of universities, colleges, and organizations across the circumpolar North, launched in 2001 as an Arctic Council program. Yukon College and Aurora College contributed to its conception and development (1997-2001) and are founding members. ${ }^{72}$ Their involvement in UArctic marks the beginning of the third stage of the "university project" in the Canadian North.

With UArctic, as with ACUNS, the territorial colleges were accepted and celebrated as peers. College involvement in UArctic expanded their reach and capacity. College students had access to UArctic undergraduate courses (Bachelor of Circumpolar Studies [BCS]), its student mobility program ("north2north"), and government-supported activities that enhanced the colleges' circumpolar capacity. Northern students travelled to Iceland, Norway, and elsewhere for study semesters and the colleges received northern students in return. Year after year, the online BCS "core courses" added northern Canadians to the number of UArctic students with a common understanding of the Arctic. ${ }^{73}$ UArctic membership also highlighted the lack of a university in the territorial Canadian North. The colleges, with their brokered degrees, fixed-cohort programs, and few research programs, were not attractive or capable research collaborators. The opportunities to be involved in research proliferated and the colleges lacked the capacity to be anything more than junior partners if they could marshal time and resources to participate at all.

Calls for a northern university began again around 2006. In the Yukon it was an election year and the NDP leader, Todd Hardy, announced in April that his party, if elected, would "move forward on creating a Yukon university"; it was, he said, simply a matter of "political will and leadership." ${ }^{74}$ Discussion continued over the summer. ${ }^{75}$ When the NDP did not win the election, the talk of a university again subsided 
(though it did not cease entirely) without having had much practical effect.

The colleges, augmented in some situations by community groups, continued much as they had in the past. They continued to offer the traditional program range while adding joint and innovative programs in response to specific needs. For example, in Nunavut in 2005, the Akitsiraq Law School with University of Victoria, produced eleven graduates. ${ }^{76}$ In 2008 in the NWT, the Dechinta Bush University Centre for Research and Learning was launched by private interests, with particular concern for Aboriginal students. ${ }^{77}$ In 2011, the Ilitturvik University Society began advocating for an Inuit university to be "a clearinghouse for Nunavut-based scholarship and activism." ${ }^{78}$ In 2011, too, a novel cultural school initiative called Piqqusilirivvik was established to be a "place for Inuit who have forgotten their Inuit ways."

What was new, though, were growing calls inside and beyond the North for a "real" university. After 2009, advocates for a northern university began raising the profile of the issue with editorials, articles, and speeches. ${ }^{80}$ The May 2009 endorsement of an Inuit university by former Governor-General, Michaëlle Jean, and the growing chorus of voices for improvement of education at all levels may have prompted the Gordon Foundation to support an encouraging "dialogue towards a university" workshop in Yellowknife in 2010. ${ }^{81}$ Canada's ArcticNet, a 1,000-member-strong network investigating change in the coastal Canadian Arctic, added an Inuit-focused post-secondary education research project in $2011 .^{82}$ The loss of federal funding for UArctic participation also encouraged more serious thinking about a northern university.

The territorial colleges exchanged views about the possibilities. Territorial government discussions in 2011 resulted in an ad hoc Northern University Working Group. ${ }^{83}$ The university idea was gaining currency. Federal and territorial northern strategy documents emphasized the importance of education being a key condition of future prosperity. ${ }^{84}$ By 2012, at the end of the UArctic period, it appeared that a university in the North would be a reality sooner rather than later. It wasn't clear what it (or they) would look like or where it (or they) would be located, but the prevailing thinking was that there would be a university of some sort somewhere in the North soon.

\section{Becoming Academic: 2012 to the present}

While campaigning in September 2011, Yukon Party leader Darrell Pasloski declared that his party wanted Yukon College "to go from being a college to a university" and he pledged to set land aside for university facilities. ${ }^{85}$ The Yukon Party won the election, and the stage was set. In February 2012, Karen Barnes, Yukon College president, announced a "Vision Team" to be a "think tank for the university development dialogue." 86 The Vision Team, tasked to propose "enhanced higher education options," canvassed staff and studied other Canadian college-to-university transitions. ${ }^{87}$ College directors polled their constituents. A report of community strategic-plan consultations was re-examined. President Barnes undertook the task of "educating" the Minister and officials of the Department of Education and the college board. 
She discussed their possible roles in a future transition. Formal institutional visits, informal meetings occasioned by other college travel, and discussions with visiting officials from as far afield as New Zealand, resulted in advice and information from almost sixty informants.

The Vision Team carried out a dozen focus-group-type consultations with faculty and staff — the so-called "Fears, Concerns, Hopes, and Dreams" sessions, an extremely productive exercise that helped, for example, to identify fears that the university would leave programs behind. The team studied institutional governance, quality assurance, and the human resource implications. A workbook explained governance options and solicited preferences and introduced quality assurance. The college began developing its own quality review processes and planned to look for a provincial quality assurance board partnership. It undertook to upgrade its governance and program reviews to university standards.

The Board of Governors' report to government on the eighteen months of inquiry was presented at the end of 2013. ${ }^{88}$ A cabinet shuffle in August 2013, however, had installed a new minister of education who wished to become thoroughly familiar with the file, so the matter remained in abeyance for most of 2014. In October, the minister made the degree announcement and declared government support for an evolutionary approach to the "creation of a university for the Yukon based on the model that is best suited for Yukoners." ${ }^{99}$ That declaration, in public, that Yukon College had government support was new and important. Fifty years and nine months after the first proposal for a university in the North, one was about to bud. ${ }^{90}$

\section{Conclusion}

For fifty years, people in and outside the territorial North have imagined, wanted, advocated, and worked for a northern university. It seems likely that a recognizable "Yukon university plus" (an institution that will retain much of its college roots) will emerge from the current processes. It is also likely that the arguments for an Inuit university to meet the specific needs and conditions of Nunavut and the other Inuit regions of Canada will win support. Many of the same arguments make it likely, too, that a similar institution will be established in the NWT, which has its own unique conditions. It is perhaps ironic that the conclusions that were drawn about the university project in the first period, soundly rejected in the late 1970s, are much the same now. One university will not fit all. A university formed of linked or federated parts, perhaps like the University of Alaska or California, with each contributing to the whole while focused on a specific part of the North, seems probable. The northern university needs to respect culture and cultural competence, and a multi-nodal institution can do that. In short, it appears that the North is ready to take on the task of building an innovative university that will serve the North and its people for generations to come. 


\section{Notes}

1 Professional degrees - Education, Social Work, and Nursing — have been routinely delivered in the North, through the colleges, by arrangement with a university that awards the degrees and whose program accreditation assures graduate competence. This degree would be the first whose quality would be assured by Yukon College.

2 Karen Barnes, email, 14 Oct. 2014. The Yukon cannot support a community college and a university. The vision is not of a university college, but something that might perhaps be imagined as a college university, one that "retains and builds on the important work we are already doing... while allowing us to expand with our own degrees and further research.”

3 The social and regular media response was minimal. At the time, @yukoncollege had about 1,200 Twitter followers and the announcement was retweeted just ten times. The two Yukon newspapers carried accounts and CBC North, Radio-Canada, and Northbeat, the CBC-TV northern news show, reported it.

4 Murray G. Ross, "Some Reflections on New Universities," in New Universities in the Modern World, edited by Murray G. Ross (London and New York: Macmillan and Company and St Martin's Press, 1966), 172.

5 For an overview, see Stefan Muthesius, The Postwar University: Utopianist Campus and College (New Haven and London: Paul Mellon Centre for Studies in British Art by Yale University Press, 2001); and Thomas C. Pocklington and Allan Tupper, No Place to Learn: Why Universities Aren't Working (Vancouver, BC: University of British Columbia Press, 2002), chap. 3.

6 Ross, "Some Reflections," 170-73. See also Paul Axelrod, Scholars and Dollars: Politics, Economics, and the Universities of Ontario 1945-1980 (Toronto: University of Toronto Press, 1982), esp. chaps. 1 to 5.

7 In NWT, 23\% of school-age children were enrolled in 1950-51. The figure rose to $75 \%$ in 1961-62. The situation was better in Yukon where access was easier. K.J. Rea, The Political Economy of the Canadian North: An Interpretation of the Course of Development in the Northern Territories of Canada to the Early 1960s (Toronto: University of Toronto Press in association with University of Saskatchewan, 1968), Table 9.4, 428.

8 Ibid. Rea notes that Diefenbaker's Roads to Resources Programme accelerated development processes underway. The result was increased expenditures, which had the consequence of making the North more socially stable. On the universities' activity in the North, see Morris Zaslow, The Northward Expansion of Canada, 1914-1967 (Toronto: McClelland and Stewart, 1988), chap. 12, "The Northern Vision and Afterwards, 1958-1967."

9 W.E. Senior, "Chance of a Lifetime," The Churchill Post: The Northlander, 30 Jan. 1964. Senior's role at the paper is unclear. The masthead reads "The Churchill Post" and the editorialist is credited as "W.E. Senior, Churchill News Editor." A Winnipeg Free Press reprint of the editorial named him "editor of the Churchill Post."

10 This provincial story is included because it is the first time a university was proposed in the North as a solution to the loss of a substantial economic driver.

11 For example, he proposed that nuclear generators be installed in the entrance to Hudson Bay to warm the water sufficiently that it would not freeze and so allow yearround commercial fishing. Gene Telpner, "Coffee Break," Winnipeg Free Press, 26 May 1966, 3.

12 This sentence and the previous one are from W. E. Senior, "The North Won't Go Away," Maclean's, 17 Oct.1964, 18.

13 W.E. Senior, "Idea for a Northern University," Winnipeg Free Press, 13 Feb. 1964, 27.

14 Senior, "The North Won't Go Away," 90.

15 Ibid. 
16 Iris Warner to Hon. Walter Dinsdale, 15 June 1964, MSS 58, f. 185, Iris Warner Collection, Yukon Archives (hereafter YA).

17 Alan Innes-Taylor, May 1964, "To Whom It May Concern: Proposal [for a University]," UCN Records, COR 0321, f. 1, YA. Innes-Taylor had a storied career that spanned both polar regions. He was particularly interested in encouraging a broader and more comprehensive scientific understanding of high-latitude regions. Philip S. Marshall, "Charles Alan Kenneth Innes-Taylor, 1900-1983," Arctic 37, 1 (1984).

18 Ibid.

19 Warner's 1964 correspondence, sketched here, is to W.A. Dempsey on 16 April, who replied to her on 21 May. She then wrote to Hon. Walter Dinsdale, in a letter on 16 July. His reply is dated 25 June 1964 and Warner's 16 Jul. 1964. These letters are in MSS 58, f. 185, Iris Warner Collection, YA.

20 Dick Hill lists three in Inuvik: A History, 1958-2008: The Planning, Construction and Growth of an Arctic Community (Victoria, BC: Trafford Publishing, 2008), 102. Six officers are listed on the application for incorporation under the NWT Societies Ordinance, "Mackenzie Institute Council Objectives and By-laws," MSS 56, f. 121, Iris Warner Collection, YA. The Institute had been operating before it was officially registered: a flyer dated November 1967 is in the same file. Warner noted that it would "offer many advantages to the Delta people" but it was, then, "little more than a desk and a telephone."

21 For the quotations and following sentences, see "Mackenzie Institute Council Objectives and By-laws," MSS 56, f. 121, Iris Warner Collection, YA.

22 Iris Warner was contracted to edit the texts.

23 Elizabeth Bell, Doug Brown, Eric Gourdeau, with Addy Tobac, "Man in the North Project Report, MIN Conference on Community Development" (Montreal, QC and Inuvik, NT: Arctic Institute of North America and Mackenzie Institute, 1970), 4.

24 This quotation and following sentence are from Hill, Inuvik: A History, 102. The timing of Allen's lectures is not clear. In an interview with the author in 1990, Hill said that many locals were presenters of the 1968 lectures.

25 Ibid., 103.

26 Robert MacDonald, "Challenges and Accomplishments: A Celebration of the Arctic Institute of North America," Arctic 58, 4 (2005): 440.

27 Peter Adams, "InfoNorth: Sixty Years of Polar Research and Teaching: The McGill Subarctic Research Station," Arctic 67, 1 (2014): 124.

28 See Axelrod, Scholars and Dollars. His description of social and political enthusiasm for universities and their broadening fields of study in the 1960s helps to explain the universities' growing northern interests. On the evolution of the Canadian university, see Pocklington and Tupper, No Place to Learn, chap. 2.

29 See the overview in Graham Rowley, Northern Studies: An Historical Perspective of the Northern Scientific Training Program (Ottawa: Indian and Northern Affairs Canada, 1988).

30 For a brief biography of Adams and an account of his post-secondary contributions, see Lesley McKarney, "Behind the Scenes of the Budget (Issues and Perspectives)," Science Careers, 4 Apr. 2003, http://sciencecareers.sciencemag.org/career_magazine/previous_ issues/articles/2003_04_04/nodoi.6269239034719611168 (accessed December 23, 2014); and Lesley McKarney, "An Academic in Ottawa," Career Magazine, 4 Apr. 2003, http://sciencecareers.sciencemag.org/career_magazine/previous_issues/ articles/2003_04_04/nodoi.2215978376747939944 (accessed 23 Dec. 2014). On the Caucus on Post-Secondary Education and on the significant education and research changes it fostered, see Paul Axelrod et al., "People, Processes, and Policy-Making in Canadian Post-Secondary Education, 1990-2000," Higher Education Policy 24, 2 (2011), 154. 
31 This account is drawn from W. Peter Adams, correspondence, 11 Nov. 1969 to 19 May 1972. W. Peter Adams Collection, Acc. 2014/98R, YA.

32 Ibid., Jean Chrétien to W.P. Adams, 14 Jan.1970.

33 Ibid., R.L. Shields to W.P. Adams, 22 Jan.1970.

34 Ibid., W.P. Adams to R.L. Shields, 10 Feb.1970.

35 On the lack of a clear vision of a northern university, see ibid. On Adams' commitment to the North and its academic development, see Peter Adams, Trent, McGill, and the North: A Story of Canada's Growth as a Sovereign Polar Nation (Peterborough, ON: Cover to Cover Publication Services, 2007).

36 See J.F. Hart with Arthur Blue, Peter Denny, and Don Simpson, "A University of the North," unpublished document, University of Western Ontario, 22 Apr. 1970. A summary, "Proposal for a University of the North," was circulated. Their year of work converged with an Association of Universities and Colleges of Canada (AUCC) plan for a June 1971 conference in the North to plumb northern needs. The Western committee was willing to help. Northern Education Committee, "Progress Report on the Northern Education Committee at the University of Western Ontario," unpublished document. All documents W. Peter Adams Collection, Acc. 2014/98R, YA. The AUCC conference was cancelled when the University of Canada North Concepts Conference was scheduled for November 1971. There is, I think, more to be learned about the work of the Northern Education Committee.

37 Nahanni was a convenor of the 1970 Man in the North Conference in Inuvik, founder of the Tree of Peace "folk-school" in Yellowknife, and a delegate to the Concepts Conference in November 1971, which is discussed below. She was the first Slavey-Dene woman to earn a Master's degree (McGill, Geography, 1992).

38 Lori Eastmure, "Honouring the Past, Touching the Future: Twenty-Two Years of Aboriginal Teacher Education in the Yukon," The Northern Review 34 (Fall 2011): esp. 41-45. On teacher training, see Frank Darnell and Anton Hoëm, Taken to Extremes: Education in the Far North (Oslo: Scandinavian University Press, 1996), 224-27.

39 David N. Wilson, "University of Canada North: Promise for an Alternative University Structure," Canadian and International Education 2, 2 (1972): 3-14. Wilson, an educational planner with African experience, drew parallels between UCN and University of Malawi. Planners of a northern university, he said, should study the experiences of the University of the West Indies, Harlem Community College, as well as those of northern universities in Alaska, Sweden, and Norway, and of the Navajo Community College.

40 The concept was presented in Acres Research and Planning Ltd., Mid-Canada Development Corridor: A Concept (Toronto, ON: Acres Research and Planning Ltd., 1967). The first session of the Mid-Canada Development Corridor Conference was held in August 1969 at Lakehead University. The second session was planned for August 1970. Amanda Graham, "The University That Wasn't: The University of Canada North, 1970-1985” (Lakehead University, 1994/2000). DOI:

10.13140/2.1.3043.2320, 34-48, gives more detail; see also the popular account of the concept by Richard Rohmer, The Green North: Mid-Canada (Toronto, ON: MacleanHunter, 1970).

41 Richard Rohmer, Generally Speaking: The Memoirs of Major-General Richard Rohmer (Toronto: Dundurn Press, 2004), 351-56.

42 Jim Lotz, Northern Realities: The Future of Northern Development in Canada (Toronto: New Press, 1970), 163.

43 Ibid., 240.

44 The condensed account in this section draws on work in Graham, "The University That Wasn't." Refer to the thesis for a full discussion of the events mentioned here. 
45 The educational and cultural landscapes of the territories were different enough to warrant considerable autonomy within the UCN whole. The divisions were variously referred to as UCN (YT) and UCN (NWT) or just as the "Yukon Division" and the "NWT Division."

46 Commissioner Stuart Hodgson to Msgr. Jacques Garneau, Association of Universities and Colleges of Canada, 4 Feb.1971. University of the North 1971. J.W.T. Spinks Fonds, University Archives and Special Collections, University of Saskatchewan.

47 Indian Brotherhood of the Northwest Territories (IBNWT), press release, "UCN-No Local Involvement," 6 Apr. 1971, UCN Records, COR 0322, f. 12, YA.

48 Initial Aboriginal objection stemmed from being excluded from the visioning. The IBNWT claimed that "nobody questions the need for a University of Canada North...but we have a concern regarding native participation...[The] Yukon Indian Brotherhood...have similar feelings." IBNWT, "The University of Canada North and the Indian people of the Northwest Territories," UCN Records, COR 0321, f. 1, YA. Chief Elijah Smith of the Yukon Native Brotherhood said, in a Globe and Mail article, that "Indians want an education up here, but not from a school that has been made behind their backs." "Indians Object to Outside Aid in North College," 7 Apr.1971, clipping in UCN Records, COR 0321, f. 3, YA.

49 For more on UCN's incorporation, see Graham, “The University That Wasn't," chap. 3, 33-49.

50 There was a lot to study. The 1970s were a period of great activity in the Canadian North. The OPEC crisis spurred domestic oil and gas exploration and the Mackenzie Valley pipeline proposal, which led to the Berger Inquiry and its large-scale background and impact research. Land claims were a developing matter, prompted in part by reaction to the 1969 White Paper on Indian Policy. The territories were busy being prepared for assumption of responsible government.

51 For an American precedent, see Steven J. Crum, "Indian Activism, the Great Society, Indian Self-Determination, and the Drive for an Indian College or University, 196471," American Indian Culture and Research Journal 31, 1 (2007): 1-20. There were also examples of nearby Aboriginal-oriented institutions, including the Inupiat University of the Arctic in Barrow, Alaska, and the Saskatchewan Indian Cultural Centre.

52 Graham, "The University That Wasn't," 70-88, examines the conference and some of the debate.

53 R.M. Hill, "Concepts of a University in Canada North," 1. "Flo Whyard," Garth Graham Collection, Acc. 2014/89R, YA. This was a conference backgrounder that had wide circulation.

54 For example, David N. Wilson, "A Study of Innovation in University Planning-The University of Canada North," research proposal, Ontario Institute of Education, 1972. UNC Records, COR 0322, f. 17, YA.

55 The NWT Division was able to secure some funding for a co-ordinator and a researcher for the "College North Project." The project is described further in Graham, "The University That Wasn't," 91-94.

56 The work of the Yukon Division of the UCN is documented in ibid., 94-125. From 1977 to 1982, the UCN Research Division, conceived and run by Ted Parnell, created what one director recalled as "a vast public presence; everybody knew about the UCN." Garth Graham, interview, Guelph, Ontario, 23 Dec. 1991.

57 Garth Graham to Catherine MacKinnon, Donner Canadian Foundation, 13 Aug. 1979. “UCN Feb. 1974 to Dec. 1980," Garth Graham Collection, Acc. 2014/89R, YA.

58 Ibid.

59 Dave Tait, "Science Centre, New PO Promised," Whitehorse Star, 4 Feb.1980, 1, 3.

60 John D. Dennison and Paul Gallagher, Canada's Community Colleges: A Critical Analysis (Vancouver: UBC Press, 2011), esp. chap. 3. 
61 Aron Senkpiel, "Postsecondary Education in the Yukon: The Last Thirty Years," in Higher Education in Canada: Different Systems, Different Perspectives, ed. Glen A. Jones (New York and London: Garland Publishing, Inc., 1997), 297. See also Gail M. Hilyer, "Higher Education in the Northwest Territories," in ibid., 301-23, on the establishment of Arctic College.

62 W.H. Stapleton, "Challenge and Change: The Development of Post Secondary Education in the NWT," in Education, Research, Information Systems and the North, Developed from the Proceedings of the ACUNS Meetings in Yellowknife, 17-19 April 1986, ed. W. Peter Adams (Ottawa, ON: Association of Canadian Universities for Northern Studies).

63 SINT was divided in 1995 in preparation for the creation of Nunavut in 1999. The daughter institutes were amalgamated with Aurora College (Aurora Research Institute) and with Nunavut Arctic College (Nunavut Research Institute).

64 Aron Senkpiel, "A New Northern Reality: Northern Research and Education at Yukon College," in The Role of Circumpolar Universities in Northern Development: Proceedings of the First Annual Conference of the Association of Circumpolar Universities, Thunder Bay, Ontario, November 24-26, 1989, Lakehead University Centre for Northern Studies Occasional Papers No. 4 (Thunder Bay: Lakehead University Centre for Northern Studies, 1991), 190-94.

65 University Transfer Division, Yukon College, "The Diploma in Northern Studies: A Proposal for Integrated Programs in Native Studies, Northern Science, and Northern Outdoor and Environmental Studies," unpublished proposal, 1988, ii-iii.

66 Senkpiel, "A New Northern Reality." For more on research at Yukon College, see The Northern Review 29 (Fall 2008), an issue on "The Northern Research Institute: Fifteen Years of Building Yukon Research Capacity."

67 Hilyer, "Higher Education in the Northwest Territories," 301-23.

68 Ibid., 302.

69 The Nunavut land claim settlement included the creation of a third northern territory by separating the Inuit traditional lands from the rest of the Northwest Territories.

70 Colleges and Continuing Education, "University College Development in the Northwest Territories: A Discussion Paper" (Yellowknife, NT: Education, Culture and Employment, Government of Northwest Territories, 1988).

71 Conversion is not without difficulties. The university enterprise can eclipse the college one: a potentially fatal flaw in the North without alternative institutions to absorb the college programs and students. See John D. Dennison, "From Community College to University: A Personal Commentary on the Evolution of an Institution," Canadian Journal of Higher Education / Revue canadienne d'enseignement supérieur 36, 2 (2006): 1-20.

72 Greg Poelzer, "The University of the Arctic: From Vision to Reality," The Northern Review 27 (Fall 2007).

73 My own count shows that between 2004 and 2010, on average 19.5 Yukon students per semester enrolled in BCS courses. UArctic's 2008 annual report said that, since 2002, 5,287 students had enrolled in BCS courses (1,754 in 2008). For commentary on UArctic programs, see Amanda Graham, "Teaching the North: The Curious Business of Being Inside-Out," Canadian Issues (Winter 2013): 23-27.

74 Julia Skikavich, "Yukon University Concept Rekindled," Whitehorse Star, 27 Apr. 2006.

75 From April to September, the Yukon university idea was local news on six occasions. An NDP-sponsored panel discussion attracted thirty-four people to "explore the economic, social and environmental impacts the creation of a Yukon university may have." Julia Skikavich, "Panel Examines Yukon University Feasibility," Whitehorse Star, 23 Aug. 2006.

76 Sarah Schmidt, "Inuit Program Produces First Law Graduates," National Post, 21 June 2005. 
77 Angela Sterrit, "Dechinta Bush University: Learning off the Land," The Tyee, 2 Oct. 2013, http://thetyee.ca/News/2013/10/22/Dechinta-Bush-University/ (accessed January 5, 2015); Jessa Gamble, "Higher Learning: Balancing Theory and Action at Canada's First Northern University," The Walrus (April 2010), 17-18.

78 Chris Windeyer, "New Group Pushes for Iqaluit-Based University," Nunatsiaq Online, July 28, 2009, http://www.nunatsiaqonline.ca/stories/article/new_group_pushes_for_ iqaluit-based_university/ (accessed 23 Dec. 2014); Gabriel Zarate, "Society Wants a University in Nunavut," Northern News Services Online, 29 July 2009, http://www.nnsl. com/frames/newspapers/2009-08/aug3_09un.html (accessed 23 Dec. 2014).

79 Emily Ridlington, "Piqqusilirivvik opens its doors," Northern News Services Online, 10 May 2011, http://www.nnsl.com/frames/newspapers/2011-05/may16_11drs.html (accessed 23 Dec. 2014).

80 See, for example, Greg Poelzer, "Arctic University Will Help Buttress Northern Strategy," Saskatoon Star-Phoenix, 22 Oct. 2009; Frances Abele and F. Leslie Seidle, "Canada Needs a University in the North," Nunatsiaq Online, 15 Oct. 2010, http:// www.nunatsiaqonline.ca/stories/article/98789_canada_needs_a_university_in_the_ north/ (accessed 23 Dec. 2014); Michaëlle Jean, "[Address at] 9th Lafontaine-Baldwin Lecture Symposium," Iqaluit, NU, 2009; John Ralston Saul, "Listen to the North," Literary Review of Canada, October 2009; Mary Simon, "A Time for Bold Action," Northern Public Affairs (2014); Sheila Watt-Cloutier, "Returning Canada to a Path of Principle: An Arctic and Inuit Perspective," speech notes for the 9th LafontaineBaldwin Lecture, Iqaluit, NU (Toronto: Institute for Canadian Citizenship, 2009); Frances Abele, "It is Time to Build a Northern University," Montreal Gazette, August 30, 2010, http://gordonfoundation.ca/op-ed/286 (accessed 23 Dec. 2014); and James Stauch, "Is It Time for a Northern University?" Northern Public Affairs (Spring 2012).

81 Blair Stevenson and Silta Associates, Dialogue Towards a University in Canada's Far North: Environmental Scan (Toronto, ON: The Gordon Foundation, 2010).

82 ArcticNet's Phase 3, IRIS 2, project, "Improving Access to University Education in the Canadian Arctic," was led by Thierry Rodon, and ran from 2011 to 2014.

83 Northern University Working Group, "Meeting Objectives," 4 July 2011.

84 Canada, Indian Affairs and Northern Development, Canada's Northern Strategy: Our North, Our Heritage, Our Future (Ottawa, ON: Indian Affairs and Northern Development, 2009); and Northwest Territories, Yukon, and Nunavut, A Northern Vision: A Stronger North and a Better Canada (Whitehorse, YT: Government of Yukon, Premier's Office, 2007).

85 Vince Fedoroff, "Costs of University's Creation Remain Unclear," Whitehorse Star, 29 Sept. 2011.

86 Karen Barnes, email to selected undisclosed Yukon College staff, invitation to join the Vision Team, 13 Feb. 2012.

87 This account of the activities of the Vision Team is drawn from the author's participation in the events described here.

88 The report has not been approved by the Board of Governors for public release.

89 Elaine Taylor, announcement made at Yukon College, 14 Oct. 2014. Videotape (4:46). Available from Yukon College.

90 Elaine Taylor and Paul Flaherty. "A Unique University Designed for Northerners Continues to Bud," Whitehorse Star, 17 Oct. 2014." 